Мануілова Катерина Віталіївна доктор наук 3 державного управління, доцент кафедри менеджменту i логістики, Одеської національної академії харчових технологій, вул. Канатна, 112, м. Одеса, 65039, тел.: (066) 223-38-62, e-mail: katerinamanyilova@gmail.com, https://orcid.org/0000-0002-0721-7232

Колеснікова Катерина Семенівна кандидат економічних наук, доцент, доцент кафедри менеджменту i логістики, Одеської національної академії харчових технологій, вул. Канатна, 112, м. Одеса, 65039, тел.: (063) 801-55-82, e-mail: ekolesnikova.od@gmail.com, https://orcid.org/0000-0001-6954-6819

Бондар Вікторія Анатоліївна кандидат економічних наук, доцент кафедри менеджменту і логістики, Одеської національної академії харчових технологій, вул. Канатна, 112, м. Одеса, 65039, тел.: (096) 584-87-58, e-mail: bondarv1801@gmail.com, https://orcid.org/ 0000-0002-0721-7232

\title{
ЕЛЕКТРОННА ДЕМОКРАТІЯ - ЕФЕКТИВНИЙ ЗАСІБ ПОДОЛАННЯ КОРУПЦІї В ПУБЛІЧНОМУ СЕКТОРІ ЕКОНОМІКИ
}

Анотація. У статті проаналізовано інструменти електронної демократії, як ефективний засіб подолання корупційних ризиків в економіки публічного сектору публічній сфері. У статті зазначено, що в сучасній Україні тривають процеси трансформації вітчизняної системи публічного управління у напрямку децентралізації влади, реформування публічного сектору економіки та створення сприятливих умов для всебічного розвитку електронної демократії з метою зменшення корупції в органах публічної влади. У державі впроваджено діджетелізацію в управління державою. В останні роки зазнають змін відносини між громадянським суспільством і політичними владою. Традиційні зв'язки між громадянами i політиками значно слабшають, все більш активніше у вітчизняному суспільстві застосовують електронні інструменти впливу на електорат. Саме застосування електронних інструментів в державі: надають можливість брати безпосередню участь громадян в управлінні державою; сприяє поліпшенню та прискоренню надання публічно-адміністративних послуг, як наслідок, діяльність уряду стає більш прозорою та відкритою, що дозволяє зменшити рівень корупції в державі; стимулює розвиток інноваційних технологій 
в державі; позитивно впливає на економічне зростання в державі та добробут населення; зміцнює засади демократії в державі через електронне врядування. Наголошено, на тому, що запровадження електронної демократії в Україні потребує подальшого моніторингу особливостей існування та визначення напрямків оптимізації та урегулювання викликів електронної демократії. Метою дослідження $є$ з'ясування стану електронного врядування в Україні та в світі визначення стану впровадження “відкритого уряду” в нашій державі, та надання рекомендацій на основі врахування світового досвіду впровадження е-демократії, щодо подальших напрямків оптимізації та урегулювання проблем електронної демократії. У досліджені з'ясовано, що успішне запровадження е-демократії безпосередньо повязано 3 соціально-економічним потенціалом держави. Чим вище рівень соціально-економічного розвитку держави, тим вище темпи розвитку е-демократії у середині держави. Данія, Південна Корея, Великобританія, Австрія, Естонія, Сінгапур мають високий рівень ВВП, тому населення країни зазвичай має високі зарплати й це сприяє всебічному розповсюдженню інноваційних технологій у середині держави. I навпаки, чим нижче рівень ВВП держави, тим нижче покажчик розповсюдження “е-демократіі” у державі. Фунціонування “е-демократії” можливо в умовах гарантування державою дієвих засобів національної безпеки спрямованої на запобігання втечі інформації про персональні данні громадян. Загалом, удосконалення інструментів “е-демократії” $\epsilon$ перспективним напрямком і нагальною необхідністю для держав світу особливо в умовах епідемій, стихійних лих, техногенних катастроф тощо. Зокрема, епідемія коронавірусу й введення карантинних заходів 3 метою запобігання розповсюдження Covid-19 у країнах світу засвідчили ефективність функціонування та нагальну необхідність запровадження “е-демократії”в державах світу.

Ключові слова: е-демократія, е-уряд, елетронний документообіг, корупція, публічний сектор економіки, диджеталізація.

Manuilova Kateryna Vitaliyivna Doctor of Science in Public Administration, Associate Professor of the Department of Management and Logistics, Odessa National Academy of Food Technologies, Kanatna St., 112, Odessa, 65039, tel.: (066) 223-3862, e-mail: katerinamanyilova@gmail.com, https://orcid.org/0000-0002-0721-7232

Kolesnikova Kateryna Semenivna Candidate of Economic Sciences, Associate Professor, Associate Professor of the Department of Management and Logistics, Odessa National Academy of Food Technologies, Kanatna St., 112, Odessa, 65039, tel.: (063) 801-55-82, e-mail: ekolesnikova.od@ gmail.com, https://orcid.org /0000-0001-6954-6819 
Bondar Victoria Anatoliyivna Candidate of Economic Sciences, Associate Professor of Management and Logistics, Odessa National Academy of Food Technologies. (Odessa), Kanatna St., 112, Odessa, 65039, tel.: (096) 584-87-58, e-mail: bondarv1801@gmail.com, https://orcid.org/0000-0002-0721-7232

\section{ELECTRONIC DEMOCRACY - AN EFFECTIVE MEANS OF OVERCOMING CORRUPTION IN THE PUBLIC SECTOR OF THE ECONOMY}

Abstract. The article analyses the tools of e-democracy as an effective means of overcoming corruption risks in the public sector economy in the public sphere. The article notes that in modern Ukraine the processes of transformation of the domestic system of public administration in the direction of decentralization of authority, reform of the public sector of the economy and creation of favourable conditions for comprehensive development of e-democracy to reduce corruption in public authorities. The state introduced digitization in the management of the state. In recent years, the relationship between civil society and political power has changed. Traditional ties between citizens and politicians are significantly weakening, and electronic tools of influencing the electorate are being used more and more actively in the domestic society. It is the use of electronic tools in the state: provide an opportunity to participate directly in the management of the state; contributes to improving and accelerating the provision of public administration services, as a result, the government's activities become more transparent and open, which reduces the level of corruption in the state; stimulates the development of innovative technologies in the state; has a positive effect on economic growth in the country and the welfare of the population; strengthens the foundations of democracy in the state through e-government. It is emphasized that the introduction of e-democracy in Ukraine requires further monitoring of the peculiarities of existence and identification of areas for optimization and resolution of the challenges of e-democracy. The purpose of the study is to clarify the state of e-government in Ukraine and in the world to determine the state of implementation of "open government" in our country, and provide recommendations based on global experience in e-democracy, further optimization and resolution of e-democracy. The study found that the successful implementation of e-democracy is directly related to the socio-economic potential of the state. The higher the level of socio-economic development of the state, the higher the rate of development of e-democracy in the middle of the state. Denmark, South Korea, the United Kingdom, Austria, Estonia, and Singapore have high levels of GDP, so the country's population usually has high salaries and this contributes to the full spread of innovative technologies within the country. Conversely, the lower the state's GDP, the lower the rate of "e-democracy" in the country. The functioning of "e-democracy" is possible in 
the conditions of the state guaranteeing effective means of national security aimed at preventing the leakage of information about personal data of citizens. In general, the improvement of the tools of "e-democracy" is a promising direction and an urgent need for the world, especially in the face of epidemics, natural disasters, man-made disasters, and more. In particular, the coronavirus epidemic and the introduction of quarantine measures to prevent the spread of David-19 in the world have demonstrated the effectiveness of the functioning and the urgent need to introduce "e-democracy" in the world.

Keywords: e-democracy, e-government, electronic document management, corruption, public sector of the economy, digitalization.

Постановка проблеми. У сучасній Україні триває вже не один рік процес трансформації вітчизняної системи публічного управління у напрямку децентралізації влади, реформування публічного сектору економіки та створення сприятливих умов для всебічного розвитку електронної демократії з метою зменшення корупції в органах публічної влади.

3 обранням Президента України В. Зеленського в нашій державі набирає обертів активна фаза впровадження диджетелізації в управління державою та створення “відкритого уряду”. В останні роки зазнають змін відносини між громадянським суспільством i політичною владою. Традиційні зв'язки між громадянами та політиками значно слабшають, все все частіше й активніше у вітчизняному суспільстві застосовують електронні інструменти (інтернет, сайти соціальних мереж, електронні 3МІ, тощо) впливу на електорат. Саме застосування різноманітних електронних інструментів в державі: по-перше, надають можливість брати безпосередню активну участь громадян в управлінні державою; по-друге, сприяє поліпшенню та прискоренню надання публічноадміністративних послуг, як наслідок, діяльність уряду стає більш прозорою та відкритою, що дозволяє зменшити рівень корупції в державі; по-третє, стимулює розвиток інноваційних технологій в державі; по-четверте, позитивно впливає на економічне зростання в державі та добробут населення; по-п'яте, зміцнює засади демократії в державі через електронне врядування або “відкритий уряд”.

Різні аспекти проблеми електронної демократії в останні роки були дослідженні науковцями. Зокрема, правові проблеми електронної демократії були досліджені О. Барановим, П. Куфтарєм, Ю. Рижуком, П. Городницьким, А. Акімовим, Я. Янсонс, А. Семенченко тощо. Політичні аспекти електронної демократії розглянуті в наукових публікаціях О. Золотар, С. Приходько, П. Клімушин, Д. Спасібов, Н. Грицяк, В. Бабич, Р. Скадовська, С. Мельник, О. Карпенко, О. Левченко та інші науковці. Т. Нижній, С. Мазур, С. Кандзюба, Р. Матвійчук, Я. Сидорович, П. Мусієнко, Т. Краснопольська, І. Милосердна та 
інші вчені розглянули у своїх наукових розробках окремі теоретичні питання електронної демократії.

Деякі питання впровадження електронної демократії в Україні стали тематикою дослідження вітчизняних науковців. Зокрема, І. Принь, Я. Жовнірчик, В. Квасюк, Ю. Ткачук, С. Кривошапка, С. Денисюк, Г. Татаренко, І Щебетун, Б.Довгань та інші дослідники.

Однак, запровадження електронної демократії (далі - е-демократія) в Україні потребує подальшого моніторингу особливостей існування, та визначення подальших напрямків оптимізації та урегулювання викликів електронної демократії.

Мета статті. З'ясування стану електронного врядування в Україні й у світі визначення стану впровадження “відкритого уряду” в нашій державі, та надання рекомендацій на основі врахування світового досвіду впровадження е-демократії, щодо подальших напрямків оптимізації та урегулювання проблем електронної демократії.

Виклад основного матеріалу. Сутністю електронної демократії на думку депутатів Європарламенту $\epsilon$ те, що “електронна демократія передбачає використання інформаційно-комунікаційних технологій (IКT) для створення каналів консультацій та участі громадськості, зокрема при проведенні виборів, консультацій або референдумів; для залучення громадян держави у процес розробки політики, для надання людям інформації та послуг в електронному вигляді'’1].

Функціонування “електронної демократії” безпосередньо пов’язано з такими інструментами як “електронні адміністративні послуги”, “електронний уряд”, “е-урядування”, “е-консультації”, “е-агітація”, “е-опитування”, “е-обговорення”, “е-форум”, “відкритий бюджет”, “бюджет участі”, “е-участь”, “е-середовище”, “е-вибори”, “е-референдуми”, “е-ініціативи”, “е-голосування”, “е-звернення”, “е-петиціï”, “е-посередництво”.

“Електронна демократія" передбачає, по суті, створення в державі сприятливих умов для становлення та функціонування електронного (хмарного) уряду (“е-уряду” або “е-урядування”).

Ключовими документами які стали законодавчою основою впровадження в нашій державі електронної демократії $\epsilon$ ряд розпоряджень кабінету міністрів України (далі - кабміну України): “Про затвердження Положення про набори даних, які підлягають оприлюдненню у формі відкритих даних" [2]; “Про схвалення Концепції розвитку електронної демократії в Україні та плану заходів щодо іï реалізації” [3]; “Про внесення змін до плану заходів щодо реалізації Концепції розвитку електронної демократії в Україні” [4]; “Про затвердження плану заходів щодо реалізації Концепції розвитку електронної демократії в 
Україні на 2019-2020 pp.” [5].

Для забезпечення керівництвом процесом електронної демократії України в нашій державі було створено 4 червня 2014 р. “Державне агентство 3 питань електронного урядування”. 329 серпня 2019 р. означене агентство було переведено до Міністерства та комітету цифрової трансформації (далі мінцифра).

До компетенції мінцифри належить широке коло компетенцій пов'язаних 3: розробкою вимог до електронного документообігу в органах влади; наданням пропозицій щодо встановлення стандартів, норм, правил, порядків, класифікаторів у сфері електронного урядування; забезпеченням інформаційної безпеки держави; створенням Єдиного державного порталу адміністративних послуг; державною реєстрацією електронних інформаційних ресурсів органів публічної влади; забезпечення функціонування Сдиного веб-порталу Кабінету Міністрів України; координацією та контролем за Національним реєстром електронних інформаційних ресурсів; забезпеченням функціонування автоматизованої системи (далі - АС) "Сдине вікно подання електронної звітності"; здійсненням заходів щодо впровадження електронного підпису; сприянням запровадження в органи публічної влади технологій електронного самоврядування та інших компетенцій пов'язаних із застосуванням інноваційних технологій [6].

Отже, розробка нормативно-правої бази та створення міністерства та комітету цифрової трансформації в нашій державі дало позитивні результати у питанні подальшого розвитку е-демократії та е-уряду в Україні. Зокрема, авторитетний комплексний покажчик Глобальний індекс розвитку електронного уряду (Global E-Government Development Index) складаний за даними Організації Об'єднаних Націй $(\mathrm{OOH})$, дозволяє простежити динаміку та рівень розвитку електронної демократії й електронного уряду в державах світу. В означеному рейтингу міститься оцінка стану розвитку електронного уряду в державах світу, а також висвітлено інформацію про спроможність національних державних структур застосовувати інформаційно-комунікаційні технології при наданні громадянам адміністративних послуг. При оцінці рівня розвитку е-демократії та електронного уряду державі за критерії беруться наступні оцінки: з'ясування ступеню охоплення та якість наданих адміністративних послуг для населення держави через інтернет (інтерент послуг); визначення рівня розвитку ІКТ інфраструктури, а також людський потенціал. Рейтинг складається раз у 2 два роки. 
Таблиия 1.1.

Динаміка розвитку електронного уряду в Україні й у державах світу

в 2012 - 2020 pp.

\begin{tabular}{|c|c|c|c|c|c|}
\hline \multirow{2}{*}{$\begin{array}{c}\text { Рік /кількість } \\
\text { держав }\end{array}$} & \multicolumn{5}{|c|}{ Місце в рейтингу /покажчик } \\
\hline & 1 місце & 2 місце & 3 місце & $\begin{array}{l}\text { Украӥна } \\
\text { / місце }\end{array}$ & $\begin{array}{l}\text { Останне місце } \\
\text { / Сомалі }\end{array}$ \\
\hline $\begin{array}{l}2012 \text { р. } \\
\text { (190 країн) }\end{array}$ & $\begin{array}{l}\text { Південна } \\
\text { Корея / } 0.9283\end{array}$ & $\begin{array}{l}\text { Нідерланди } \\
\text { / } 0.9125\end{array}$ & $\begin{array}{l}\text { Велика } \\
\text { Британія } \\
/ 0.8960\end{array}$ & $\begin{array}{l}68 / \\
0.5653\end{array}$ & $/ 0.0640$ \\
\hline $\begin{array}{l}2014 \text { р. } \\
\text { (193 країни) }\end{array}$ & $\begin{array}{l}\text { Південна } \\
\text { Корея / } 0.9462\end{array}$ & $\begin{array}{l}\text { Австралія } \\
/ 0.9103\end{array}$ & $\begin{array}{l}\text { Сінгапур } \\
/ 0.9076\end{array}$ & $\begin{array}{l}87 / \\
0.5032\end{array}$ & 0.0139 \\
\hline $\begin{array}{l}2016 \text { р. } \\
\text { (193 країни) }\end{array}$ & $\begin{array}{l}\text { Велика } \\
\text { Британія } \\
/ 0.9193\end{array}$ & $\begin{array}{l}\text { Австралія } \\
\text { / } 0.9143\end{array}$ & $\begin{array}{l}\text { Південна } \\
\text { Корея /0.8915 }\end{array}$ & $\begin{array}{l}62 / \\
0.6076\end{array}$ & 0.0270 \\
\hline $\begin{array}{l}2018 \text { р. } \\
\text { (193 країни) }\end{array}$ & Данія /0,9150 & $\begin{array}{l}\text { Австралія / } \\
0,9053\end{array}$ & $\begin{array}{l}\text { Південна } \\
\text { Корея } \quad 0,9010\end{array}$ & $\begin{array}{l}82 \text { місце } \\
/ 0,6165\end{array}$ & 0.0270 \\
\hline $\begin{array}{l}2020 \text { р. } \\
\text { (193 країни) }\end{array}$ & Данія /0,9758 & $\begin{array}{l}\text { Південна } \\
\text { Корея } \\
\text { / 0,956 } 1\end{array}$ & $\begin{array}{l}\text { Естонія } \\
/ 0,9473\end{array}$ & $\begin{array}{l}69 \text { місце } \\
\text { /0,7119 }\end{array}$ & 0,0566 \\
\hline
\end{tabular}

(складено на за даними Global E-Government Development Index OOH протягом 2012 - 2020 рр. К. Мануіловою, К. Колесніковою, В. Бондарь) [7; 8; 9, с. 154 - 159; 10 , c. $221-227 ; 11$, c. $267-273]$.

Данія останні чотири роки займає перше місце в рейтингу Global E-Government Development Index. Ключовим напрямком розвитку е-уряду Данії $\epsilon$ створення передумов для користування цифровими сервісами всіх громадян. Для розв'язання означених завдань уряд Данії створив так звані “правильні ресурси для надання допоміжних цифрових послуг” у приміщеннях органів державної влади, бібліотеках тощо для тих, хто не засвоїв цифрові сервіси. Таким чином, Данія в 2019 р. мала найвищий рівень використання цифрових державних послуг в ОЕСР близько 70\%. Зокрема, через інтернет у Данії надаються такі електронні адміністративні послуги, як прийняття на роботу, і зокрема, заяву на допомогу у зв'язку 3 вагітністю та пологами має цифровий коефіцієнт прийняття $100 \%$, реєстрація для отримання початкового і неповної середньої освіти має коефіцієнт прийняття 97\%, і навіть заяву на державну пенсію має коефіцієнт 95\% [12].

Отже, як видно із таблиці 1.1. ще однією з держав, успішно розвивається електронна демократія $є$ Південна Корея. Зокрема, південнокорейський е-уряд надає своїм громадянам понад 1000 адміністративних послуг, таких як податки, митне оформлення та закупівлі [13]. Ключовою особливістю е-демократії 
Південної Кореї є те що, в цій державі термін «електронний уряд» іноді замінюють терміном «мобільне уряд». Надалі у Південній Кореї планується подальшому розвивати платформу на підтримку мобільної роботи державних органів та надання державних послуг “в будь-якому місці в будь-який час”[14].

Висновки. Втім, “е-демократія" має свої виклики. По-перше, успішне запровадження демократії безпосередньо пов'язано 3 соціально-економічним потенціалом держави. Чим вище рівень соціально-економічного розвитку держави, тим вище темпи розвитку “е-демократії” у середині держави. Так, такі держави, як Данія, Південна Корея, Великобританія, Австрія, Естонія, Сінгапур мають високий рівень ВВП, тому населення країни зазвичай має високі зарплати й це сприяє всебічному розповсюдженню інноваційних технологій у середині держави. I навпаки, чим нижче рівень ВВП держави, тим нижче покажчик розповсюдження “е-демократії” у державі.

По-друге, функціонування “е-демократії” можливо в умовах гарантування державою дієвих засобів національної безпеки спрямованої на запобігання втечі інформації про персональні данні громадян.

Загалом, впровадження й удосконалення інструментів “е - демократії" $\epsilon$ перспективним напрямком i нагальною необхідністю для всіх держав світу особливо в умовах епідемій, стихійних лих, техногенних катастроф тощо. Зокрема, епідемія коронавірусу й введення карантинних заходів 3 метою запобігання розповсюдження Covid-19 у країнах світу засвідчили ефективність функціонування і нагальну необхідність запровадження “е-демократіі”в державах світу.

\section{Jimepamypa:}

1. E-democracy: opportunities and risks. News Euro parlament. 15-03-2017. - Режим доступу: https://www.europarl.europa.eu/news/en/headlines/society/20170224STO63943/edemocracy-opportunities-and-risks (дата звернення: 10.02.2021).

2. Розпорядження кабінету міністрів України: "Про затвердження Положення про набори даних, які підлягають оприлюдненню у формі відкритих даних” від 21 жовтня 2015 р. № 835 Урядовий кур'єр від 24.10.2015.

3. Розпорядження кабінету міністрів України від 8 листопада 2017 р. № 797-р. : “Про схвалення Концепції розвитку електронної демократії в Україні та плану заходів щодо іiі реалізаціі”від 8 листопада 2017 р. № 797-р. Офіційний вісник України від 24.11.2017 - 2017 р., № 92, стор. 75, стаття 2803, код акта 87966/2017.

4. Розпорядження кабінету міністрів України: "Про внесення змін до плану заходів щодо реалізації Концепції розвитку електронної демократії в Україні”від 14 лютого 2018 р. № 98-р. Офіційний вісник України від 02.03 .2018 - 2018 р., № 18, стор. 61, стаття 616, код акта $89229 / 2018$.

5. Розпорядження кабінету міністрів України: "Про затвердження плану заходів щодо реалізації Концепції розвитку електронної демократії в Україні на 2019-2020 рр.” від 12 червня 
2019 р. № 405-р. Урядовий кур'єр від 14.06.2019. № 111.

6. Міністерство економічного розвитку i торгівлі. Платформа ефективного регулювання. PRO. Державне агентство з питань електронного урядування України.- Режим доступу: https://regulation.gov.ua/catalogue/regulators/id63/functions/page-2 (дата звернення: 11.02.2021).

7. Исследование ООН: Рейтинг стран мира по уровню развития электронного правительства 2012 года. Электронный ресурс. Центр гуманитарных технологий. 09.03.2012. Режим доступу: https://gtmarket.ru/news/2012/03/09/4102 https://regulation.gov.ua/catalogue/regulators/id63/functions/page-2 (дата звернення: 08.02.2021).

8. Исследование ООН: Рейтинг стран мира по уровню развития электронного правительства 2014 года. [Электронный ресурс]. Центр гуманитарных технологий. 26.06.2014. - Режим доступу: https://gtmarket.ru/news/2014/06/26/6835 (дата звернення: 10.01.2021).

9. United nations e-government survey 2016. Department of Economic and Social Affairs E-government in support of sustainable development.UNITED NATIONS New York, 2016. 242 p.

10. Департамент по экономическим и социальным вопросам исследование ООН: Электронное правительство 2018 применение электронного правительства для формирования устойчивого и гибкого общества ОРГАНИЗАЦИЯ ОБЪЕДИНЕННЫХ НАЦИЙ. Нью-Йорк, 2018. 299 c.

11. Исследование ООН: Электронное правительство 2020 Цифровое правительство в десятилетии действий по достижению устойчивого развития С дополнением по реагированию на COVID-19. ОРГАНИЗАЦИЯ ОБЪЕДИНЕННЫХ НАЦИЙ. Нью-Йорк, 2020. 236 с.

12. Danish Ambassador Lars Thuesen, Embassy of Denmark in United Kingdom. How Denmark made it to the top in e-Government.Posted on 1st April 2019. - Режим доступу: https://digileaders.com/how-denmark-made-it-to-the-top-in-e-government/ (дата звернення: 18.12.2020).

13. Korea's Government Integrated Data Center Sets a New Benchmark on e-Government. Korea. IT. Times. Global News Network. - Режим доступу: http://www.koreaittimes.com/news/articleView.html?idxno=19156 (дата звернення: 27.11.2020).

14. Электронное правительство в Южной Корее. - Режим доступу: https://elgov.ucoz.ru/index/ehlektronnoe_pravitelstvo_v_juzhnoj_koree/0-9 (дата звернення: 17.12.2020).

\section{References:}

1. E-democracy: opportunities and risks. (2017.) News Euro parlament. Retrieved from: https://www.europarl.europa.eu/news/en/headlines/society/20170224STO63943/e-democracyopportunities-and-risks

2. Rozporiadzhennia kabinetu ministriv Ukrainy vid 8 lystopada 2017 r. № 797-r. : "Pro skhvalennia Kontseptsii rozvytku elektronnoi demokratii v Ukraini ta planu zakhodiv shchodo yii realizatsii”vid 21 zhovtnia 2015 r. № 835 Uriadovyi kurier vid 24.10.2015.[Order of the Cabinet of Ministers of Ukraine: "On approval of the Regulations on data sets to be published in the form of open data" dated October 21, 2015 № 835 Uriadovyi kurierdated 24.10.2015.] (October 21. 10. 2015). № 835 Uriadovyi kurier vid 24.10.2015 [in Ukrainian].

3. Rozporiadzhennia kabinetu ministriv Ukrainy vid 8 lystopada 2017 r. № 797-r. : "Pro skhvalennia Kontseptsii rozvytku elektronnoi demokratii v Ukraini ta planu zakhodiv shchodo yii realizatsii'” № 797-p. (November 8, 2017). [Order of the Cabinet of Ministers of Ukraine of 
November 8, 2017 № 797-r. : “On approval of the Concept for the development of e-democracy in Ukraine and the action plan for its implementation” of November 8, 2017 № 797-p. Ofitsiinyi visnyk Ukrainy dated 24.11.2017 - 2017, № 92, p. 75, Article 2803, act code 87966/2017]. Ofitsiinyi visnyk Ukrainy vid 24.11.2017 - 2017 r., № 92, stor. 75, stattia 2803, kod akta 87966/2017. [in Ukrainian].

4. Rozporiadzhennia kabinetu ministriv Ukrainy: "Pro vnesennia zmin do planu zakhodiv shchodo realizatsii Kontseptsii rozvytku elektronnoi demokratii v Ukraini”vid 14 liutoho 2018 r. № 98-r. Ofitsiinyi visnyk Ukrainy vid 02.03.2018 - 2018 r., № 18, stor. 61, stattia 616, kod akta 89229/2018. (02.03.2018) [Order of the Cabinet of Ministers of Ukraine: "On Amendments to the Action Plan for the Implementation of the Concept for the Development of Electronic Democracy in Ukraine" of February 14, 2018 № 98-r. Official Gazette of Ukraine dated March 2, 2018 - 2018, № 18, p. 61, Article 616, act code 89229/2018] [in Ukrainian].

5. Rozporiadzhennia kabinetu ministriv Ukrainy: "Pro zatverdzhennia planu zakhodiv shchodo realizatsii Kontseptsii rozvytku elektronnoi demokratii v Ukraini na 2019-2020 rr." vid 12 chervnia 2019 r. № 405-r. Uriadovyi kurier vid 14.06.2019. № 111. (14.06.2019). [Order of the Cabinet of Ministers of Ukraine: "On approval of the action plan for the implementation of the Concept for the development of electronic democracy in Ukraine for 2019-2020." from June 12, 2019 № 405-r. Government courier dated June 14, 2019. № 111] [in Ukrainian].

6. Ministerstvo ekonomichnoho rozvytku i torhivli. Platforma efektyvnoho rehuliuvannia. PRO. Derzhavne ahentstvo z pytan elektronnoho uriaduvannia Ukrainy. (2021) [Ministry of Economic Development and Trade. Effective regulation platform. PRO. State Agency for eGovernment of Ukraine]. Retrieved from: https://regulation.gov.ua/catalogue/regulators/id63/ functions/page-2 [in Ukrainian].

7. Issledovaniye OON: Reyting stran mira po urovnyu razvitiya elektronnogo pravitelstva 2012 goda. Elektronnyy resurs. Tsentr gumanitarnykh tekhnologiy. 09.03.2012. (2012) [UN study: Rating of countries in the world by the level of development of e-government 2012. [Electronic resource]. Center for Humanitarian Technologies. 09.03.2012. Retrieved from: https://gtmarket.ru/news/2012/03/09/4102

https://regulation.gov.ua/catalogue/regulators/id63/functions/page-2 [in Russian].

8. Issledovaniye OON: Reyting stran mira po urovnyu razvitiya elektronnogo pravitelstva 2014 goda. [Elektronnyy resurs]. Tsentr gumanitarnykh tekhnologiy. 26.06.2014. [UN's study: Ranking of countries in the world by the level of e-government development in 2014. Center for Humanitarian Technologies. 26.06.2014]. Retrieved from: https://gtmarket.ru/news/2014/06/ 26/6835 [in Russian].

9. United nations e-government survey 2016. Department of Economic and Social Affairs E-government in support of sustainable development.UNITED NATIONS New York, 2016. 242 p.

10. Departament po ekonomicheskim i sotsialnym voprosam issledovaniye OON: Elektronnoye pravitelstvo 2018 primeneniye elektronnogo pravitelstva dlya formirovaniya ustoychivogo i gibkogo obshchestva Organizatsiya Obyedinennykh Natsiy. Nyu-York. 2018. 299 s. (2018) [Department of Economic and Social Affairs UN Study: E-Government 2018 Applying e-Government to building a Sustainable and Resilient Society UNITED NATIONS. New York, 2018.299 p.] [in Russian].

11. Issledovaniye OON: Elektronnoye pravitelstvo 2020 Tsifrovoye pravitelstvo v desyatiletii deystviy po dostizheniyu ustoychivogo razvitiya $S$ dopolneniyem po reagirovaniyu na COVID-19. Organizatsiya Obyedinennykh Natsiy. Nyu-York. 2020. 236 s. (2020) [UN Study: E-Government 2020 Digital Government in a Decade of Action for Sustainable Development With 
COVID-19 Response Supplement. UNITED NATIONS. New York, 2020.236 p.] [in Russian].

12. Danish Ambassador Lars Thuesen, Embassy of Denmark in United Kingdom. How Denmark made it to the top in e-Government.Posted on 1st April 2019. Retrieved from: https://digileaders.com/how-denmark-made-it-to-the-top-in-e-government/

13. Korea's Government Integrated Data Center Sets a New Benchmark on e-Government. Korea. IT. Times. Global News Network. Retrieved from: http://www.koreaittimes.com/news/articleView.html?idxno=19156 [in Russian].

14. Elektronnoye pravitelstvo v Yuzhnoy Koreye. [Electronic government in South Korea]. Retrieved from: https://elgov.ucoz.ru/index/ehlektronnoe_pravitelstvo_v_juzhnoj_koree/0-9 [in Russian]. 